\title{
Real Wages and the Demand for Skilled and Unskilled Male Labour in Ghana's Manufacturing Sector: 1991-1995
}

\author{
Francis Teal
}

\section{WPS/97-10}

\author{
May 1997 \\ Centre for the Study of African Economies \\ Institute of Economics and Statistics \\ University of Oxford \\ St Cross Building \\ Manor Road \\ Oxford OX1 3UL.
}

Key words: Labour markets, wage determination, labour demand in Ghana.

JEL Classification: J30 and O55.

Correspondence: Dr F J Teal, Centre for the Study of African Economies.

The data used in this paper was collected over the period 1992 to 1996 by a team from the Centre for the Study of African Economies (CSAE), University of Oxford, the University of Ghana, Legon and the Ghana Statistical Office, Accra. The first three surveys, from 1992 to 1994, were part of the Regional Program on Enterprise Development (RPED) organised by the World Bank. The questionnaire was designed by a team from the World Bank. Andrew Oswald and John Knight have offered much useful advice and assistance. I am greatly indebted to Walter Elkan for criticisms and comments on an earlier version of this paper. Two referees have made very helpful and constructive suggestions which have led to major changes and improvements in the paper. All remaining errors are my own. The research was undertaken as part of the Employment and Labour Markets Research Programme funded by the Overseas Development Administration (ODA), now the Department for International Development. The CSAE is funded by the Economic and Social Research Council of the UK.

\footnotetext{
Abstract: Real wage rates in Ghana have fallen substantially over the last twenty years. In this paper survey data for the years 1991-1996 is used to assess whether this fall has continued in the 1990s. It is shown that the fall in average real wage rates has continued, the relative wage of skilled labour has risen, the share of skilled wages in total wages has remained constant and the share of wages in value-added has risen. Factor share equations for skilled and unskilled labour are estimated which are consistent with the rise in skilled wages leading to substitution to unskilled labour and with technical regress raising the demand for unskilled labour. Real wage income in the sample has risen over the period.
} 



\section{Contents}

1. Introduction 1

2. The Data 1

3. Real Wages in Ghana 2

4. The Demand for Skilled and Unskilled Labour 4

5. Some Objections, Alternative Specifications and Implications 6

6. Summary and Conclusions 7

$\begin{array}{lr}\text { References } & 8\end{array}$

$\begin{array}{ll}\text { Tables } & 9\end{array}$

Appendix of Information on Sample and Variable Definitions 17 



\section{Introduction}

Wages for unskilled, relative to skilled, workers have been falling in many developed countries since the 1970s. There are broadly two hypotheses to explain this pattern. It is argued by Wood (1994) that the expansion of trade in labour-intensive goods has put downward pressure on unskilled wages in the traded sector. An alternative hypothesis is that the rise in skilled wages is the result of skill-biased technical change occurring in developed countries (Bound and Johnson 1992, Krueger 1993 and Bell 1996). The two explanations are not mutually exclusive. In the context of developing countries, the rapidly growing NICs have experienced sustained rises in real wages while elsewhere real wages have stagnated or fallen (Horton, Kanbur and Mazumdar 1994). In the context of sub-Saharan Africa the focus has been on the substantial falls in real wages which have occurred (Jamal and Weeks 1993). Levy and Newman (1989) show for the Côte d'Ivoire that a measured rise in real wages, while employment fell over the period 1979 to 1984, hides changes in composition such that, for a given skill level, real wages fell.

In this paper, employee- and firm-level information from a survey of Ghana's manufacturing sector, which is described in the next section, is used to examine changes in both skilled and unskilled earnings. The data set has recall data on earnings so it is possible to examine, in more detail than is usually possible for African labour markets, the pattern of real wage changes over time. In section 3 the evidence for changes in real wages in Ghana since the 1970s is set out. For the period since 1992 it is possible to show that the relative price of skilled labour has been rising. Estimates of factor cost share equations are presented in section 4 as a means of establishing the extent of substitutability between capital and both skilled and unskilled labour. Some possible objections to the procedure are considered in section 5 where the implications for labour demand of changing relative factor prices and technical change are presented. Section 6 concludes the paper.

\section{The Data}

The data set used in this paper is taken from a panel survey of firms in Ghana in which workers within the firms were interviewed at the same time as data was collected on firm output and performance. The surveys cover the years 1991 to 1995 for firm information and provide individual earnings data for the period 1992 to 1996. The original sampling was done on the basis of the 1987 Census of Manufacturing Activities (Ghana 1987a). The evidence suggests that the Industrial Census greatly under-recorded the number of small enterprises in the economy. Steel and Webster (1991, p. 6) use the Population Census (Ghana 1987b), and Industrial Statistics to estimate that in 1984 there were more than 500,000 persons employed in enterprises with less than 30 employees. The 1987 Industrial Census identified about 50,000 employees of such enterprises in less than 8,000 establishments. Further, the 1987 Industrial Census showed far more workers in the sector employing more than 30 workers than do the figures from the Industrial Statistics - about twice as many. It appears that the 1987 Industrial Census omitted most smallscale enterprises from its coverage while the Industrial Statistics greatly underestimate employment in firms of more than 30 employees. ${ }^{1}$

Four size categories were used to structure the sample: micro, which was defined as firms

\footnotetext{
$1 \quad$ The figures from Steel and Webster (1991) and those from the Industrial Census are presented in Appendix Tables A1 and A2.
} 
employing less than five; small firms, employing between 5 and 29 persons; medium firms, employing from 30 to less than 100 persons and large firms, employing more than 100 . In the sampling from the Industrial Census large enterprises were oversampled. The two other criteria used in stratifying the sample were the sector and location of the firms. It was initially decided to focus on four sectors - food, textiles and garments, wood and metal - which together comprised some 70 per cent of employment. Investigation of the data from the census indicated that a finer classification would be useful. Two sectors, textiles and wood, have relatively large firms while furniture and garments are dominated by very small firms. The initial sample was structured to cover firms from six sectors ranging in size from micro to large. ${ }^{2}$

The sample of workers and apprentices chosen from each firm was designed to cover the full range of personnel employed by the firms. The objective was to have up to 10 workers and 10 apprentices from each firm where firm size allowed. As a result of this survey design it is possible to estimate both individual-level equations and firm-level ones. The paper exploits that opportunity.

\section{Real Wages in Ghana}

While there is no doubt that real wages in Ghana have fallen, both the extent of the fall and its pattern over time are uncertain. If the index of the official minimum wages is used, then calculations presented by Adelman (1991, p. 76) show that real wages in 1985 were at 28 per cent of their 1975 value, an annualised rate of fall of 12.6 per cent per annum. There are two problems with using minimum wage rates to infer changes in actual wages. The first is that there is much evidence that minimum wages are not paid in the small-scale sector and that, in the large-firm sector, actual wages are well above minimum wage rates. The second problem with using minimum wage rates is that they do not include firm-specific allowances which are an important source of wages at both the bottom and the top of the wages scale. The data set used in this paper allows both these issues to be addressed more directly than is possible with official statistics. In the first round of the surveys workers and apprentices were asked both their basic wage and allowances. During the course of the surveys allowances were being consolidated into basic pay so the distinction was becoming blurred. In this paper 'wages' refers to both basic wages and allowances. It is, so far as possible, the total remuneration of the employee.

A comparison of minimum wage rates with starting wages for production workers over the period 1970 to 1995 is presented in Table $1 .^{3}$ For nearly all years, recalled starting wages were substantially higher than the official minimum wage, confirming the dangers of using the minimum wage rates to infer actual wages. Real minimum wages reached their lowest point in 1983, the year when the first of the structural adjustment reforms was introduced. Since that year the real minimum wage has doubled while the real value of starting wages has seen no sustained change. There does not appear to be any evidence from this time series data that the minimum wage sets

\footnotetext{
There was some slippage from sample design to outcome as a large number of textile firms had closed. The detail of the final sample chosen by sector and firm size is given in Appendix Table A3.

As part of the survey, workers were asked their pay when they started to work at their current firm. While this data is problematic, given the very high rates of inflation in Ghana, it nevertheless presents a picture of starting wages for those employees who answered this question. The actual wages data referred to in Table 1 is the recalled starting wages of workers when first employed in their current firm.
} 
a floor for the private sector. The substantial rises in real minimum wages that have occurred since the early 1980s have left their level still substantially below starting wages in the manufacturing sector. Both sets of data confirm that the precipitous fall in real wages of the 1970s has not continued. Real starting wages in the early 1990s were half the level of the early 1970s and there is no evidence of sustained rises.

The evidence from Table 1 does not imply that real wages for all workers failed to rise in the early 1990s. The wage index in Table 1 is for the pay of workers when they began their jobs with the firm. Such workers are younger than the average and younger workers, as will be shown, are paid substantially less than older ones. Table 2 presents the wages of all male workers and a breakdown between skilled and unskilled workers, for the five years for which there is data. Skilled workers are defined as those classified as managers, sales, administration or supervisors. As is shown in Appendix Table A4, this occupational classification mirrors the education levels of the workforce, so skilled workers are those whose education level is above the average. The breakdown in Table 2 shows that the fall in average real wages was entirely confined to the unskilled; real wages for the skilled did not fall.

The possibility of a widening gap between lower- and higher-paid workers can be investigated further by looking at the data for apprentices' wages. Apprentices are employees in small firms who are taken on by a master as trainees. Many are not paid, and those who are paid receive substantially lower wages than those in larger firms. Table 3 shows that over the period of the survey the percentage being paid fell from 91.1 per cent to 79.8 per cent while, for those paid, real wages fell by 46 per cent, a much larger fall than occurred for unskilled workers generally.

The implication of Tables 2 and 3 is that it should be possible to detect in the earnings function a rise in the relative price of skilled labour. Table 4 presents a standard earnings function, for male full-time employees, where we proceed from the general occupational classification to one using the definition of skilled and unskilled labour given in Appendix Table A4 and which will be the basis of the labour demand functions presented in the next section. The earnings function in Table 4 Equation [1] shows that the underlying increase in nominal earnings over the period was 190 per cent, while the nominal price level rose by 280 per cent, confirming the results of earlier tables of a substantial fall in average real wages over the period. Table 4 Equation [2] replaces the occupational classification by a single summary variable for whether or not the worker is skilled. The equation shows that the average skilled differential is 62 per cent. In Table 4 Equation [3] the skill dummy is interacted with the year to show that this differential more than doubles over the course of the survey. There is compelling evidence that the relative price of skilled labour rose over the survey period. The issue that will be investigated in the next section is how far the changing pattern of demand for labour can be explained by this relative price change. 


\section{The Demand for Skilled and Unskilled Labour}

In this section the changing composition of the workforce in the firms is examined. The rise in the relative price of skilled labour will, if skilled and unskilled labour are close substitutes, have led to some decline in the demand for skilled relative to unskilled labour. To assess the consequences for labour demand it is also necessary to establish the extent of substitution between both classes of labour and capital. The approach adopted is to estimate factor cost share equations from a translog cost function which is of the form:

$$
\operatorname{Ln} C=\operatorname{Ln} Y+a_{0}+\sum a_{i} L n w_{i}+0.5 \sum \sum b_{i j} L n w_{i} w_{j}
$$

with $\sum a_{i}=1, b_{i j}=b_{j i}, \sum b_{i j}=0$, for all $j$,

where $\mathrm{C}$ is cost, $\mathrm{Y}$ output and $\mathrm{w}_{\mathrm{i}}$ are factor prices.

The first and third equalities in [1] result from the assumption that $\mathrm{C}$ is linear homogeneous in the $\mathrm{w}_{\mathrm{i}}$. The second assumption stems from the requirement of the cost function that the cross-partial derivatives be equal.

From this cost function it is possible to derive a set of share equations that are linear in the production parameters. As there are five years of data for the firms it is possible to allow for firm fixed effects in the estimation.

$$
\mathrm{s}_{\mathrm{it}}=\mathrm{a}_{\mathrm{i}}+\sum \mathrm{b}_{\mathrm{ij}} \operatorname{Ln~w}_{\mathrm{jt}}+\epsilon_{\mathrm{it}}, \mathrm{i}=1 \ldots . \mathrm{N},
$$

where $s_{i t}$ is the factor share of the $i^{\text {th }}$ firm at time $t$ and $a_{i}$ is the firm-specific effect.

In this system the partial elasticities of substitution (see Hamermesh 1993, p. 41) are:

$$
\begin{aligned}
& \sigma_{i j}=\left(b_{i j}+s_{i} s_{j}\right) / s_{i} s_{j}, \quad i \neq j . \\
& \sigma_{i i}=\left(b_{i i}+s_{i}^{2}-s_{i}\right) / s^{2}{ }_{i}
\end{aligned}
$$

In estimating these factor share equations it is necessary to estimate both the prices of the two classes of labour and the capital costs facing the firm. The sample is restricted to firms with male workers. The prices of skilled and unskilled labour have been estimated from earnings functions where the determinants of earnings are the human capital characteristics of the workers. The prices for skilled and unskilled wages used in the regressions reported below are the predicted values from these functions. The price of capital has been measured by taking the ratio of pre-tax profits to the value of the capital stock where the pre-tax profit is calculated from the data on value-added and costs. The use of such a procedure to measure the cost of capital to the firm assumes that this profit rate varies across firms and over time and that it is not possible, in the context of African capital markets, to assume there is a given exogenous cost of capital to the firm. Whether the results are sensitive to this assumption will be considered in the next section.

Table 5 presents the unrestricted estimates of the levels and differenced specification for the factor cost share equations. The differenced specification allows for firm fixed effects. Homogeneity implies that the coefficients on the factor price terms should sum to zero, a restriction that is 
rejected for the levels equations but accepted for the differences. This suggests that the rejection of homogeneity is due to firm fixed effects. The share equations include time dummies in the level equations, which can be interpreted as picking up underlying technical change. There is a highly significant trend increase in the share of unskilled labour in total cost.

One possible explanation for this finding is the very low levels of investment. The median values of investment, either to value-added or capital, are less than 1 per cent in the Ghanaian manufacturing sector (Bigsten et al. 1997). It can be argued that these rates of investment are too low to enable the real capital stock to rise. One interpretation of the rising share of unskilled labour in total cost is that technical regress is ensuring a rising demand for unskilled labour substituting for the capital stock. If true, this process would be the converse of that observed in developed country markets. Machin, Ryan and Van Reenen (1996) present comparative evidence for the US and Europe, where there have been rises both in relative wage rates for skilled workers and in the share of wages going to skilled labour, of the importance of skill-biased technical progress. They find that expenditures on industry-specific R\&D raise both the share of wages going to skilled labour and the proportion of skilled labour in the workforce. The interpretation of the Ghanaian data as the converse of their findings is consistent with both formal and informal evidence for the failure of technical progress to occur in the manufacturing sector. Lall et al. (1994, p. 43) find that 'R\&D effort in Ghana relevant to manufacturing industry is minuscule, well below the critical mass needed to make a significant contribution to the absorption, adaption or creation of technology'. CSAE (1995) shows negative total factor productivity from an estimate of factor inputs in the sector and substantial falls in labour productivity. All this evidence is consistent with technical regress.

It is necessary next to consider the degree of substitution implied by the share equations. We focus on the fixed effects estimators as it is clear from Table 5 that fixed effects are important. In Table 6 the share equations are presented first with the homogeneity assumption and then with a restriction that the cross-price terms in the equation are zero, all restrictions accepted by the data. The two key factor substitutions that are relevant are the degree of substitutability between skilled and unskilled labour and between the two classes of labour and capital. The implied elasticities of substitution are shown at the bottom of Table 6 .

Two results emerge. One is the relative ease of substitution between skilled and unskilled labour. The second is that the elasticity of substitution between unskilled labour and capital is greater than the elasticity of substitution between skilled labour and capital. It can be shown that this implies that the elasticity of complementarity between skilled labour and capital is greater than that between unskilled labour and capital (Fallon and Layard 1975, p. 283). The elasticity of complementarity refers to the effect on factor prices of changes in factor quantities. If, as the low rates of investment suggest, the real capital stock has been falling this should have resulted in a fall in the relative price of skilled labour - the opposite of what has occurred. The interpretation of the findings advanced here is that this is further evidence that the rise in the price for skilled labour can be treated as exogenous to the manufacturing sector and that the rising demand for unskilled labour is the result of both this exogenous rise in the price of skilled labour and the effects of technical regress in the firms. 


\section{Some Objections, Alternative Specifications and Implications}

Before turning to the implications of the results some objections to the specifications presented in the previous section will be considered. The results reported in the last section for the degree of substitutability between labour and capital hinge on the price of capital variable that has been constructed from the data on profits. It could be argued that this procedure is flawed for at least two reasons. One is that measurement error in profits will lead to a serious error in the estimates of the coefficients on the profit term. Second, this term is endogenous so there will be simultaneity bias combined with the bias from measurement error. To investigate the importance of these objections a specification for the share of skilled labour in the total wage is presented in Table 7 . Equation [1] shows the level equation and there is a clear trend decline in the share of skilled labour in the total, a result consistent with the rise in the share of unskilled labour shown in Table 5. As with the earlier equations the homogeneity assumption is rejected for the levels but accepted for the differenced specification (Table 7 Equation [2]). The implied elasticity of substitution between skilled and unskilled labour is 0.3 which is substantially below the estimate of unity obtained from the more general specification.

The key result of the earlier analysis, which this alternative specification confirms, is that the rise in the relative price of skilled labour has not been associated with a rise in the share of skilled labour in total wages. If the elasticity of substitution of 0.3 is accepted then, given the constancy of the share of skilled wages in the total, the implication must be that the decline in technical progress has been accelerating. The large and significant coefficient on the time dummy in Table 7 implies that result. We would argue that a more reasonable inference is that the results in Table 7 are misspecified by the omission of the capital price series and that this misspecification has resulted in a downwards bias in the estimate of the elasticity of substitution between skilled and unskilled labour.

While the results of Tables 6 and 7 imply different weighting for the role of labour substitution and technical progress, both imply that the demand for unskilled labour will be rising for three reasons. First, the relative price of unskilled to skilled labour is falling; second, technical regress is increasing the demand for unskilled labour; and, finally, demand for unskilled-labour-intensive goods will have risen as their price has fallen. It is clearly possible that the rising demand for labour will have resulted in rises in real wage income. Whether that has occurred in this sample of firms is shown in Table 8 where real wage income, as distinct from real wage rates, is shown for both skilled and unskilled labour. Between 1991 and 1995 the rise in the real value of unskilled wage income was greater than the rise in real skilled wage income. It is important not to put too much weight on this comparison as no clear trend is apparent in the data. Real unskilled wage income was lower in 1995 than 1992. However, both the regression results, and the data reported in Table 8, strongly suggest that focusing on wage rates will mislead as a measure of the consequences for wage income. Further, in this developing country data set, the results suggest that rises in the wages of skilled labour have a much less adverse effect on inequality than has been the case in developed countries. 


\section{Summary and Conclusions}

The experience of workers in Africa has been very different from the experience of those in developed countries, and in other parts of the developing world. The fall in real wages in Ghana, as in other African countries, over the last twenty years has been very substantial. By the early 1990s real wages in Ghana were half those of the mid-1970s. Over the recent past declines have continued and, within this average decline, those who are lowest-paid have experienced the largest falls in real wages. The spread of earnings is widening as the average falls. In this paper the implications for skilled and unskilled labour demand have been investigated.

The major empirical finding of the paper is that, while the relative wage of skilled labour has been rising, this has not resulted in a rise in the share of skilled labour in total wages. While the rise in skilled wage rates is similar to patterns in many developed countries, it has been argued that the causes cannot be found in skill-biased technical change. The different effects which are observed - substantial substitution to unskilled labour and no change in the share of skilled labour - are due to two factors. One is the relatively high degree of substitutability between unskilled and skilled labour. The second is the consequence of technical regress which, it has been argued, has acted to increase the demand for unskilled labour. The result in the sample has been rises in real wage income for both skilled and unskilled workers. 


\section{References}

Alderman, H. (1991), 'Downturn and economic recovery in Ghana: Impacts on the poor', Cornell Food and Nutrition Policy Program, Monograph 10, March.

Bell, B. (1996), 'Skill-biased technical change and wages: evidence from a longitudinal data set', Discussion Paper No. 8, The Labour Market Consequences of Technical and Structural Change, CEP, LSE, and IES, Oxford.

Bigsten, A., P. Collier, S. Dercon, B. Gauthier, J. W. Gunning, A. Isaksson, A. Oduro, R. Oostendorp, C. Pattillo, M. Soderbom, M. Sylvain, F. Teal and A. Zeufack (1997), 'Investment in Africa's Manufacturing Sector: a Four Country Panel Data Analysis', CSAE Working Paper Series 97-11, Oxford.

Bound, J. and G. Johnson (1992), 'Changes in the structure of wages in the 1980s: an evaluation of alternative explanations', American Economic Review, 82, 3, pp. 371-392.

CSAE (1995), 'The Ghanaian manufacturing sector 1991-1993', mimeo, December, Oxford.

Fallon, P.R. and P. R. G. Layard (1975), 'Capital-skill complementarity, income distribution, and output accounting', Journal of Political Economy, 83, 2, pp. 279-299.

Ghana (1987a), Central Bureau of Statistics, Industrial Census 1987, Statistical Service, Accra. Ghana (1987b), 1984 Population Census of Ghana, Statistical Service, Accra.

Hamermesh, D.S. (1993), Labor Demand, Princeton University Press, Princeton.

Horton, S., R. Kanbur and D. Mazumdar (1994), 'Labor markets in an era of adjustment: an overview', Chapter 1 in S. Horton, R. Kanbur and D. Mazumdar (eds), Labor markets in an Era of Adjustment, Volume 2, EDI Development Studies, The World Bank, Washington.

Jamal, V. and J. Weeks (1993), Africa Misunderstood or Whatever Happened to the Rural-Urban Gap?, Macmillan for the ILO.

Knight, J., L. Song and J. Huaibin (1997), 'Chinese rural migrants in urban enterprises: three perspectives', Applied Economics Discussion Paper No. 190, January, Institute of Economics and Statistics, University of Oxford.

Kreuger, A. B. (1993), 'How computers have changed the wage structure: evidence from microdata, 1984-1989', Quarterly Journal of Economics, 108, 33-60.

Lall, S., G. B. Navaretti, S. Teitel and G. Wignaraja (1994), Technology and Enterprise Development: Ghana under Structural Adjustment, Macmillan, London.

Machin, S., A. Ryan and J. Van Reenen (1996), 'Technology and changes in skill structure: evidence from an international panel of industries', Discussion Paper No. 4, The Labour Market Consequences of Technical and Structural Change, CEP, LSE, and IES, Oxford.

Levy, V. and J. L. Newman (1989), 'Wage rigidity: micro and macro evidence on labor market adjustment in the modern sector', The World Bank Economic Review, vol. 3, no. 1, pp. 97-117. Steel, W. F. and L. M. Webster (1991), Small Enterprises under Adjustment in Ghana, World Bank Technical Paper Number 138, Industry and Finance Series.

White, H. (1980), 'A heteroscedasticity-consistent covariance matrix estimator and a direct test for heteroscedasticity', Econometrica, 48, 817-838.

Wood, A. (1994), North-South Trade, Employment and Inequality: Changing fortunes in a skilldriven world, Clarendon Press, Oxford. 


\section{Tables}

Table 1: Minimum Wage Rates and Starting Wages for Production Workers in Ghana: 1970-1995

\begin{tabular}{|c|c|c|c|c|c|c|}
\hline & $\begin{array}{l}\text { CPI } \\
1977= \\
100\end{array}$ & $\begin{array}{l}\text { Minimum } \\
\text { wages (a) } \\
\text { Cedis } \\
\text { per month }\end{array}$ & $\begin{array}{l}\text { Actual } \\
\text { wages } \\
\text { Cedis } \\
\text { per mol }\end{array}$ & & $\begin{array}{l}\text { Real } \\
\text { minimum } \\
\text { wages } \\
1977 \text { Cedis }\end{array}$ & $\begin{array}{l}\text { Real } \\
\text { actual } \\
\text { wages } \\
\text { month } \\
\end{array}$ \\
\hline 1970 & 13.8 & 20 & 43 & [6] & 145 & 312 \\
\hline 1971 & 15.1 & 20 & 40 & {$[15]$} & 132 & 265 \\
\hline 1972 & 16.7 & 27 & 32 & [9] & 162 & 192 \\
\hline 1973 & 19.6 & 32 & 41 & [18] & 163 & 209 \\
\hline 1974 & 23.0 & 54 & 54 & [20] & 235 & 235 \\
\hline 1975 & 29.6 & 54 & 54 & {$[28]$} & 182 & 182 \\
\hline 1976 & 48.2 & 54 & 92 & [23] & 112 & 191 \\
\hline 1977 & 100.0 & 81 & 150 & {$[36]$} & 81 & 150 \\
\hline 1978 & 174.1 & 130 & 188 & [23] & 134 & 145 \\
\hline 1979 & 270.4 & 130 & 400 & [30] & 48 & 148 \\
\hline 1980 & 407.5 & 173 & 558 & {$[36]$} & 42 & 137 \\
\hline 1981 & 881.7 & 389 & 520 & [35] & 44 & 59 \\
\hline 1982 & 1062.4 & 389 & 750 & [43] & 37 & 71 \\
\hline 1983 & 2367.4 & 705 & 3,050 & {$[62]$} & 30 & 129 \\
\hline 1984 & 3304.2 & 1100 & 4,600 & [54] & 33 & 139 \\
\hline 1985 & $3,647.2$ & 2268 & 4,500 & [89] & 62 & 123 \\
\hline 1986 & 4543.1 & 3546 & 7,000 & {$[90]$} & 78 & 154 \\
\hline 1987 & $6,352.0$ & 5535 & 7,000 & [137] & 87 & 110 \\
\hline 1988 & $8,343.9$ & 7481 & 12,000 & [122] & 90 & 144 \\
\hline 1989 & $10,449.3$ & 8079 & 15,000 & [143] & 77 & 144 \\
\hline 1990 & $14,341.5$ & 9931 & 18,000 & [132] & 69 & 126 \\
\hline 1991 & $16,932.5$ & 12,420 & 16,000 & [195] & 73 & 94 \\
\hline 1992 & $18,629.7$ & 14,877 & 21,000 & [209] & 80 & 113 \\
\hline 1993 & 23,280 & 17,820 & 36,000 & [89] & 77 & 155 \\
\hline 1994 & 29,069 & 21,330 & 45,000 & [108] & 73 & 155 \\
\hline 1995 & 53,364 & 32,400 & 52,000 & [81] & 61 & 97 \\
\hline
\end{tabular}

(a) The figures for 1975 and 1980 are taken from Alderman (1991, p. 76). The figures after 1980 were supplied by the Ghana Statistical Office. Since 1977 there has been both a statutory minimum wage and minimum allowances. The figures given include these minimum allowances. Rates are cited on a daily basis and have been converted to a monthly rate by assuming 27 working days per month.

(b) Actual wages are the median values of reported wages of production workers in the surveys for their pay when they started work in their current firm. These figures thus refer to the starting pay of workers in the formal, ie wage-paying, sector. The figures in [ ] brackets are the numbers of observations on which the figures are based. 
Table 2: Nominal and Real Wages for Male Workers and Apprentices who Earn in Ghana: Evidence from the Surveys 1992-1996

in Cedis per month (a)

\begin{tabular}{|c|c|c|c|c|c|}
\hline \multicolumn{2}{|c|}{ Unskilled } & \multicolumn{2}{|c|}{ Skilled } & All & \\
\hline Nominal & Real & Nominal & Real & Nominal & Real \\
\hline
\end{tabular}

\begin{tabular}{|c|c|c|c|c|c|c|c|}
\hline \multirow[t]{3}{*}{1992} & Mean & 20,571 & \multirow[t]{3}{*}{110} & 45,480 & \multirow[t]{3}{*}{244} & 27,395 & \multirow[t]{3}{*}{147} \\
\hline & Std & 15,237 & & 30,261 & & 23,278 & \\
\hline & $\mathrm{N}$ & 432 & & 163 & & 595 & \\
\hline \multirow[t]{3}{*}{1993} & Mean & 25,536 & \multirow[t]{3}{*}{110} & 70,060 & \multirow[t]{3}{*}{301} & 37,242 & \multirow[t]{3}{*}{160} \\
\hline & Std & 20,663 & & 49,342 & & 36,561 & \\
\hline & $\mathrm{N}$ & 485 & & 173 & & 658 & \\
\hline \multirow[t]{3}{*}{1994} & Mean & 30,307 & \multirow[t]{3}{*}{104} & 87,023 & \multirow[t]{3}{*}{299} & 38,806 & \multirow[t]{3}{*}{133} \\
\hline & Std & 26,259 & & 63,170 & & 39,886 & \\
\hline & $\mathrm{N}$ & 851 & & 150 & & 1,001 & \\
\hline \multirow[t]{3}{*}{1995} & Mean & 44,003 & \multirow[t]{3}{*}{82} & 149,973 & \multirow[t]{3}{*}{281} & 71,950 & \multirow[t]{3}{*}{135} \\
\hline & Std & 62,328 & & 288,873 & & 164,283 & \\
\hline & $\mathrm{N}$ & 751 & & 269 & & 1,020 & \\
\hline \multirow[t]{3}{*}{1996} & Mean & 57,586 & \multirow[t]{3}{*}{78} & 197,627 & \multirow[t]{3}{*}{266} & 95,181 & \multirow[t]{3}{*}{128} \\
\hline & Std & 51,423 & & 194,037 & & 125,976 & \\
\hline & $\mathrm{N}$ & 763 & & 280 & & 1,043 & \\
\hline
\end{tabular}

Mean is the mean of the sample, Std is the standard deviation and $\mathrm{N}$ is the number of observations.

(a) Nominal wages are in cedis per month. Real wages are in 1977 cedis per month. If the figures are converted to US\$ per month then the earnings of the workers are as follows:

Unskilled workers

$\begin{array}{lllll}1992 & 1993 & 1994 & 1995 & 1996 \\ 47 & 39 & 32 & 37 & 35 \\ 104 & 108 & 91 & 125 & 119\end{array}$

Skilled workers

For comparative purposes it can be noted that an enterprise survey in China for 1995 reports average monthly earnings for production workers of US\$ 68 and for management workers of US\$ 106, Knight, Song and Huaibin (1997, p. 7).

(b) Unskilled workers are defined as those in occupational classifications maintenance, production, masters and apprentices. Skilled workers are defined as those in occupational classifications management, administration, sales and supervisors (see Appendix Table A4). 
Table 3: $\quad$ Real Wages for Male Apprentices in Ghana:

Evidence from the Surveys 1992-1996

in Cedis per month (a)

$\begin{array}{llll}\begin{array}{l}\text { Percentage being } \\ \text { paid }\end{array} & \begin{array}{l}\text { Nominal } \\ \text { average } \\ \text { wages }\end{array} & \begin{array}{l}\text { Nominal } \\ \text { wages } \\ \text { if paid }\end{array} & \begin{array}{l}\text { Real } \\ \text { wages } \\ \text { if paid }\end{array}\end{array}$

\begin{tabular}{llllll}
1992 & Mean & 91.1 & 8,221 & 9,020 & 48 \\
& Std & 28.5 & 7,455 & 7,332 & \\
& $\mathrm{~N}$ & 158 & 158 & 144 & \\
& & & & & \\
1993 & Mean & 89.5 & 7,522 & 8,407 & 36 \\
& Std & 30.8 & 6,930 & 6,799 & \\
& $\mathrm{~N}$ & 152 & 152 & 136 & \\
1994 & Mean & 89.3 & & & 24 \\
& Std & 31.0 & 6,194 & 6,940 & \\
& $\mathrm{~N}$ & 243 & 6,337 & 6,310 & \\
1995 & Mean & 79.8 & 242 & 216 & \\
& Std & 40.2 & 13,966 & 17,503 & 33 \\
& $\mathrm{~N}$ & 287 & 17,909 & 18,442 & \\
& & & 287 & 229 & \\
1996 & Mean & 79.8 & & & \\
& Std & 40.2 & 15,120 & 18,950 & 26 \\
& $\mathrm{~N}$ & 287 & 18,274 & 18,600 & \\
& & & 287 & 229 & \\
\hline
\end{tabular}

Mean is the mean of the sample, Std is the standard deviation and $\mathrm{N}$ is the number of observations.

(a) Nominal wages are in cedis per month. Real wages are in 1977 cedis per month. 
Table 4: $\quad$ Earnings Equation for All Full-Time Male Workers and Apprentices who Earn Dependent Variable Ln (Earnings)

\begin{tabular}{|c|c|c|c|}
\hline & Equation [1] & Equation [2] & Equation [3] \\
\hline Constant & $\begin{array}{l}6.98 \\
{[63.9]}\end{array}$ & $\begin{array}{l}5.30 \\
{[42.5]}\end{array}$ & $\begin{array}{l}5.36 \\
{[42.5]}\end{array}$ \\
\hline Age & 0.075 & 0.200 & 0.20 \\
\hline & [11.6] & {$[29.2]$} & [29.4] \\
\hline $\mathrm{Age}^{2}$ & $\begin{array}{l}-0.001 \\
{[9.8]}\end{array}$ & $\begin{array}{l}-0.002 \\
{[23.6]}\end{array}$ & $\begin{array}{l}-0.002 \\
{[23.8]}\end{array}$ \\
\hline Education & 0.03 & 0.04 & 0.04 \\
\hline (in years) & [7.9] & [11.1] & {$[10.7]$} \\
\hline Tenure & 0.003 & 0.003 & 0.003 \\
\hline (in years) & {$[1.5]$} & {$[1.7]$} & [1.8] \\
\hline Management & $\begin{array}{l}2.20 \\
{[34.9]}\end{array}$ & & \\
\hline Administration & $\begin{array}{l}1.73 \\
{[29.8]}\end{array}$ & & \\
\hline Sales & $\begin{array}{l}1.49 \\
{[28.4]}\end{array}$ & & \\
\hline Supervisor & $\begin{array}{l}1.62 \\
{[32.5]}\end{array}$ & & \\
\hline Maintenance & $\begin{array}{l}1.35 \\
{[29.1]}\end{array}$ & & \\
\hline Master & $\begin{array}{l}1.31 \\
{[26.9]}\end{array}$ & & \\
\hline Production & $\begin{array}{l}1.26 \\
{[32.0]}\end{array}$ & & \\
\hline Skilled workers & & $\begin{array}{l}0.48 \\
{[18.3]}\end{array}$ & $\begin{array}{l}0.26 \\
{[4.4]}\end{array}$ \\
\hline Year 1993 & $0.23[6.8]$ & $0.29[7.3]$ & $0.25[4.9]$ \\
\hline Dummy1994 & $0.30[9.1]$ & $0.33[8.6]$ & $0.27[5.7]$ \\
\hline 1995 & $0.77[21.1]$ & $0.75[18.6]$ & $0.68[13.5]$ \\
\hline 1996 & $1.07[29.9]$ & $1.06[26.4]$ & $0.96[19.1]$ \\
\hline Year * 1993 & & & $0.16[2.1]$ \\
\hline Skill 1994 & & & $0.22[2.9]$ \\
\hline 1995 & & & $0.25[3.1]$ \\
\hline 1996 & & & $0.37[4.6]$ \\
\hline Adjusted $\mathrm{R}^{2}$ & 0.69 & 0.56 & 0.56 \\
\hline$\chi^{2}$ (White test) (DF) & $395(96)$ & $285(42)$ & $303(58)$ \\
\hline Number of obs. & 4111 & 4111 & 4111 \\
\hline
\end{tabular}

The figures in [] brackets are the absolute value of $t$ statistics which have been corrected by the method due to White (1980). 
Table 5: $\quad$ Factor Cost Shares: unrestricted specification

Dependent Variable: Share of Unskilled and Skilled Labour in Value-added

\begin{tabular}{|c|c|c|c|c|}
\hline \multirow[b]{2}{*}{ Intercept } & \multicolumn{2}{|c|}{ Levels specification (a) } & \multicolumn{2}{|c|}{ Differenced specification } \\
\hline & $\begin{array}{l}\text { Unskilled } \\
1.72 \\
{[3.9]}\end{array}$ & $\begin{array}{l}\text { Skilled } \\
-0.15 \\
{[0.6]}\end{array}$ & $\begin{array}{l}\text { Unskilled } \\
0.01 \\
{[0.4]}\end{array}$ & $\begin{array}{l}\text { Skilled } \\
0.01 \\
{[0.6]}\end{array}$ \\
\hline $\begin{array}{l}\text { Ln (Unskilled } \\
\text { wage) }\end{array}$ & $\begin{array}{l}-0.05 \\
{[1.5]}\end{array}$ & $\begin{array}{l}0.01 \\
{[0.4]}\end{array}$ & $\begin{array}{l}0.01 \\
{[0.1]}\end{array}$ & $\begin{array}{l}-0.03 \\
{[1.0]}\end{array}$ \\
\hline $\begin{array}{l}\text { Ln (Skilled } \\
\text { wage) }\end{array}$ & $\begin{array}{l}-0.10 \\
{[2.2]}\end{array}$ & $\begin{array}{l}0.02 \\
{[0.8]}\end{array}$ & $\begin{array}{l}-0.01 \\
{[0.2]}\end{array}$ & $\begin{array}{l}0.04 \\
{[1.0]}\end{array}$ \\
\hline $\begin{array}{l}\text { Ln (Profit } \\
\text { rate) }\end{array}$ & $\begin{array}{l}-0.06 \\
{[11.2]}\end{array}$ & $\begin{array}{l}-0.02 \\
{[5.7]}\end{array}$ & $\begin{array}{l}-0.07 \\
{[6.2]}\end{array}$ & $\begin{array}{l}-0.02 \\
{[4.9]}\end{array}$ \\
\hline Wave 2 & $\begin{array}{l}0.09 \\
{[2.6]}\end{array}$ & $\begin{array}{l}-0.02 \\
{[0.9]}\end{array}$ & $\begin{array}{l}0.01 \\
{[0.4]}\end{array}$ & $\begin{array}{l}-0.02 \\
{[1.1]}\end{array}$ \\
\hline Wave 3 & $\begin{array}{c}0.12 \\
{[2.9]}\end{array}$ & $\begin{array}{l}-0.05 \\
{[1.9]}\end{array}$ & $\begin{array}{l}-0.03 \\
{[0.8]}\end{array}$ & $\begin{array}{l}-0.01 \\
{[0.4]}\end{array}$ \\
\hline Wave 4 & $\begin{array}{l}0.17 \\
{[3.6]}\end{array}$ & $\begin{array}{l}-0.05 \\
{[1.8]}\end{array}$ & $\begin{array}{l}0.08 \\
{[2.4]}\end{array}$ & $\begin{array}{l}-0.03 \\
{[1.3]}\end{array}$ \\
\hline Wave 5 & $\begin{array}{l}0.24 \\
{[3.8]}\end{array}$ & $\begin{array}{l}-0.05 \\
{[1.4]}\end{array}$ & & \\
\hline $\begin{array}{l}\text { Adjusted } \mathrm{R}^{2} \\
\text { White } \chi^{2}(\mathrm{DF}) \\
\mathrm{N}\end{array}$ & $\begin{array}{l}0.35 \\
142(120) \\
285\end{array}$ & $\begin{array}{l}0.28 \\
114(120) \\
285\end{array}$ & $\begin{array}{l}0.40 \\
25(21) \\
148\end{array}$ & $\begin{array}{l}0.13 \\
20(21) \\
148\end{array}$ \\
\hline
\end{tabular}

(a) These equations include controls for location, sector and ownership.

The figures in [ ] brackets are the absolute value of $t$ statistics which have been corrected by the method due to White (1980).

Shares of Factors in Value-added

Mean Standard deviation

Skilled labour

$0.12 \quad 0.12$

Unskilled labour

$0.29 \quad 0.21$

Capital

0.59

0.24 
Table 6: $\quad$ Factor Cost Shares: restricted specifications

Dependent Variable: Share of Unskilled and Skilled Labour in Value-added

\begin{tabular}{|c|c|c|c|c|}
\hline \multicolumn{5}{|c|}{ Differenced specification } \\
\hline & Unskilled & Skilled & Unskilled & Skilled \\
\hline Intercept & $\begin{array}{l}-0.02 \\
{[1.1]}\end{array}$ & $\begin{array}{l}0.01 \\
{[0.6]}\end{array}$ & $\begin{array}{l}-0.01 \\
{[0.9]}\end{array}$ & $\begin{array}{l}0.01 \\
{[0.8]}\end{array}$ \\
\hline $\begin{array}{l}\text { Ln (Profit rate/ } \\
\text { unskilled wage) }\end{array}$ & $\begin{array}{l}-0.04 \\
{[0.9]}\end{array}$ & $\begin{array}{l}0.02 \\
{[0.9]}\end{array}$ & $\begin{array}{l}-0.07 \\
{[6.5]}\end{array}$ & \\
\hline $\begin{array}{l}\text { Ln (Profit rate/ } \\
\text { skilled wage) }\end{array}$ & $\begin{array}{l}-0.03 \\
{[0.8]}\end{array}$ & $\begin{array}{l}-0.05 \\
{[1.9]}\end{array}$ & & $\begin{array}{l}-0.02 \\
{[4.5]}\end{array}$ \\
\hline Wave 2 & $\begin{array}{l}0.002 \\
{[0.1]}\end{array}$ & $\begin{array}{l}-0.02 \\
{[1.3]}\end{array}$ & $\begin{array}{l}0.001 \\
{[0.1]}\end{array}$ & $\begin{array}{l}-0.03 \\
{[1.4]}\end{array}$ \\
\hline Wave 3 & $\begin{array}{l}-0.01 \\
{[0.4]}\end{array}$ & $\begin{array}{l}-0.01 \\
{[0.3]}\end{array}$ & $\begin{array}{l}-0.02 \\
{[0.6]}\end{array}$ & $\begin{array}{l}-0.01 \\
{[0.5]}\end{array}$ \\
\hline Wave 4 & $\begin{array}{l}0.08 \\
{[2.6]}\end{array}$ & $\begin{array}{l}-0.03 \\
{[1.2]}\end{array}$ & $\begin{array}{l}0.08 \\
{[2.6]}\end{array}$ & $\begin{array}{l}-0.03 \\
{[1.2]}\end{array}$ \\
\hline $\begin{array}{l}\text { Adjusted } \mathrm{R}^{2} \\
\text { White } \chi^{2}(\mathrm{DF}) \\
\mathrm{N}\end{array}$ & $\begin{array}{l}0.40 \\
20(14) \\
148\end{array}$ & $\begin{array}{l}0.13 \\
13(14) \\
148\end{array}$ & $\begin{array}{l}0.41 \\
17(8) \\
148\end{array}$ & $\begin{array}{l}0.13 \\
4(8) \\
148\end{array}$ \\
\hline
\end{tabular}

The figures in [ ] brackets are the absolute value of $t$ statistics which have been corrected by the method due to White (1980).

\section{Elasticities of substitution between}

skilled and unskilled labour $\quad=\quad 1.0$

skilled labour and capital $=(-0.02+0.12 \times 0.59) / 0.12 \times 0.59 \quad=0.4$

unskilled labour and capital $=(-0.07+0.29 \times 0.59) / 0.29 \times 0.59=0.6$ 
Table 7: $\quad$ Skilled Wage Share

Dependent Variable: Share of Skilled Wages in Total Wages

Levels specification (a) Differenced specification

$\begin{array}{llll}\text { Intercept } & -1.7 & 0.01 & 0.03 \\ & {[3.1]} & {[0.2]} & {[1.9]} \\ \begin{array}{l}\text { Ln (Unskilled } \\ \text { wage) }\end{array} & 0.05 & -0.12 & \\ & {[1.5]} & {[1.4]} & \\ \text { Ln (Skilled } & 0.16 & 0.17 & \\ \text { wage) } & {[3.1]} & {[2.4]} & \\ & & & \\ \text { Ln (Unskilled/ } & & & -0.14 \\ \text { skilled wage) } & & & {[2.5]} \\ & & -0.07 & -0.06 \\ \text { Wave 2 } & -0.11 & {[1.9]} & {[1.9]} \\ & {[2.3]} & & \\ & & -0.02 & -0.03 \\ \text { Wave 3 } & -0.19 & {[0.6]} & {[0.9]} \\ & {[4.1]} & & \\ \text { Wave 4 } & -0.29 & -0.13 & -0.13 \\ & {[4.8]} & {[2.6]} & {[2.7]}\end{array}$

Wave $5-0.35$

[4.6]

$\begin{array}{llll}\text { Adjusted } \mathrm{R}^{2} & 0.32 & 0.11 & 0.12 \\ \text { White } \chi^{2}(\mathrm{DF}) & 118(106) & 22(14) & 17(8) \\ \mathrm{N} & 285 & 148 & 148\end{array}$

(a) These equations include controls for location, sector and ownership

The figures in [ ] brackets are the absolute value of $t$ statistics which have been corrected by the method due to White (1980).

Elasticity of substitution between

skilled and unskilled labour $=(-0.14+0.3 \times 0.7) / 0.3 \times 0.7=0.3$ 
Table 8: $\quad$ Wages and the Skill Composition of the Workforce in the Firms

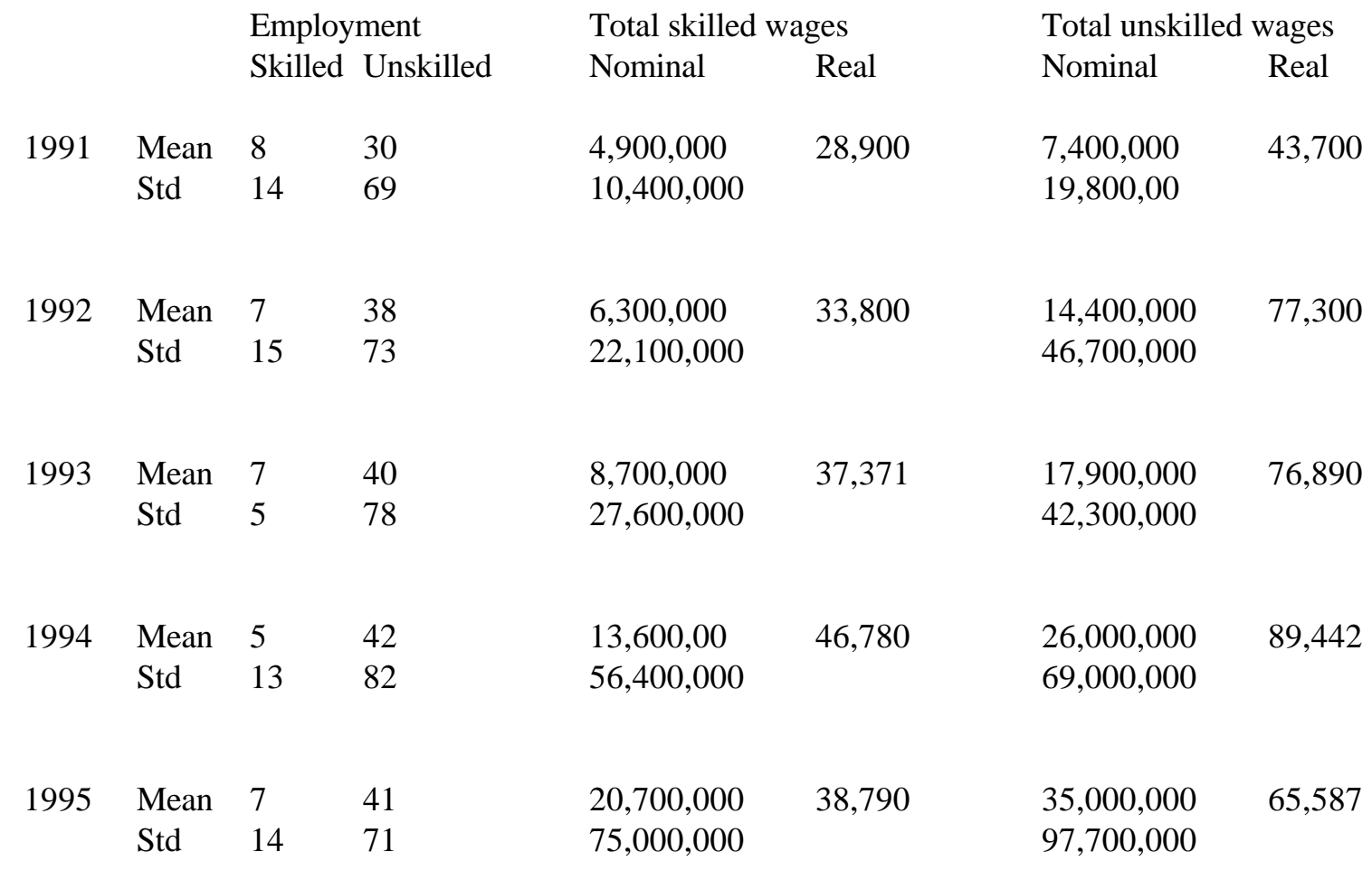

$\mathrm{N}=47$ 


\section{Appendix of Information on Sample and Variable Definitions}

Table A1

The Distribution of Employment by Size of Enterprise

\begin{tabular}{llll}
\hline $\begin{array}{l}\text { Employment } \\
\text { (No. of workers) }\end{array}$ & $\begin{array}{l}\text { Small- } \\
\text { scale } \\
(1)\end{array}$ & $\begin{array}{l}\text { Large- } \\
\text { scale } \\
(2)\end{array}$ & Total \\
\hline & & & \\
1963 & 245,187 & 31,865 & 277,052 \\
1970 & 358,958 & 55,899 & 414,857 \\
1973 & 363,524 & 64,000 & 427,524 \\
1984 & 532,585 & 55,783 & 588,368 \\
\hline
\end{tabular}

Source: Steel and Webster (1991, p. 6). Large-scale enterprises are those which employ more than 30 people. 'Small-scale' is all other employment, defined as the difference between the population census number in column (3) and the employment in large-scale enterprises in column (2).

Table A2 Manufacturing Industry Ghana: The 1987 Industrial Census

\begin{tabular}{llllll}
\hline & & & & & \\
Employment size & $1-4$ & $5-29$ & $30-99$ & $>100$ & Total \\
Number of workers & 7,400 & 42,805 & 21,710 & 85,169 & 157,084 \\
Establishment & 2,884 & 4,802 & 423 & 242 & 8351 \\
& & & & & \\
\hline
\end{tabular}

Source: Industrial Census Ghana (1987a).

Table A3 The Structure of the Final Sample by Sector and Size

\begin{tabular}{llllll} 
& Micro & Small & Medium & Large & Total \\
\hline Food processing & 18 & 15 & 10 & 7 & 50 \\
Textiles & 1 & 1 & 3 & 1 & 6 \\
Garments & 11 & 23 & 8 & 1 & 43 \\
Wood products & 3 & 2 & 1 & 5 & 11 \\
Furniture & 5 & 22 & 8 & 5 & 40 \\
Metal working & 6 & 27 & 10 & 7 & 50 \\
Total & 44 & 90 & 40 & 26 & 200 \\
\hline
\end{tabular}


Table A4

Skilled Workers and Occupational Classification

\begin{tabular}{|c|c|c|c|c|}
\hline \multicolumn{2}{|c|}{ Occupational classification } & $\begin{array}{l}\text { Education } \\
\text { in years }\end{array}$ & $\begin{array}{l}\text { Age } \\
\text { in years }\end{array}$ & $\begin{array}{l}\text { Earnings } \\
\text { Cedis per month }\end{array}$ \\
\hline \multicolumn{5}{|c|}{ Skilled Occupations } \\
\hline \multirow[t]{3}{*}{ Management } & Mean & 14.6 & 45 & 201,506 \\
\hline & Std & 3.9 & 10.6 & 272,955 \\
\hline & $\mathrm{N}$ & 228 & 228 & 215 \\
\hline \multirow{3}{*}{ Administration } & Mean & 13.5 & 40.1 & 129,223 \\
\hline & Std & 3.5 & 11.2 & 248,869 \\
\hline & $\mathrm{N}$ & 285 & 286 & 276 \\
\hline \multirow[t]{3}{*}{ Sales } & Mean & 13.6 & 38.7 & 86,182 \\
\hline & Std & 2.6 & 10.0 & 61,202 \\
\hline & $\mathrm{N}$ & 246 & 246 & 237 \\
\hline \multirow[t]{3}{*}{ Supervisors } & Mean & 11.4 & 40.7 & 87,593 \\
\hline & Std & 2.9 & 10.1 & 70,268 \\
\hline & $\mathrm{N}$ & 367 & 367 & 364 \\
\hline
\end{tabular}

\section{Unskilled Occupations}

\begin{tabular}{lllll} 
Maintenance & Mean & 10.3 & 36.4 & 59,175 \\
& Std & 3.5 & 10.4 & 42,765 \\
& $\mathrm{~N}$ & 360 & 360 & 350 \\
& & & & \\
\multirow{2}{*}{$\begin{array}{l}\text { Production, support } \\
\text { workers }\end{array}$} & Mean & 10.2 & 34.0 & 49,252 \\
& Std & 3.6 & 10.2 & 50,937 \\
& $\mathrm{~N}$ & 1459 & 1459 & 1416 \\
Masters & & & & \\
& Mean & 9.4 & 31.8 & 54,487 \\
& Std & 3.4 & 9.4 & 40,225 \\
Apprentices & $\mathrm{N}$ & 342 & 343 & 330 \\
& & & 21.3 & 10,914 \\
& Mean & 9.4 & 3.6 & 14,265 \\
& Std & 3.0 & 1123 & 1126 \\
\hline \multirow{2}{*}{ ALL } & $\mathrm{N}$ & 1123 & & \\
& & & 32.6 & 58,446 \\
\hline
\end{tabular}


Table A5: $\quad$ Variable Definitions and Means

Age The age of the worker.

$\mathrm{Age}^{2} \quad$ The age of the worker squared.

Education The education of the worker in years. This variable was constructed from answers as to the final stage of school or university completed. It is treated as a continuous variable although we cannot measure years of education from this data set quite that precisely.

Tenure Years in current job.

The ownership dummies included in the regressions are:

State Ownership Dummy $=1$ for some State Ownership (if the firm had both state and foreign ownership it was placed in the Foreign Ownership category).

Foreign Ownership Dummy $=1$ for any Foreign Ownership. The omitted category is thus firms with solely Ghanaian owners.

The location dummies included in the regressions are:

ACCRA Dummy variable $=1$ for living in Accra.

KUM Dummy variable $=1$ for living in Kumasi.

TAK Dummy variable $=1$ for living in Takoradi.

CAPE Dummy variable $=1$ for living in Cape Coast.

The sector dummies included in the regressions are:

FOODS Dummy $=1$ for Food Sector which comprises SIC categories

3110-3139 (except 3117).

BAKERY Dummy $=1$ for Bakery which comprises SIC category 3117.

WOOD Dummy $=1$ for Wood Sector which comprises SIC categories 3310-3319.

FURN $\quad$ Dummy $=1$ for Furniture Sector which comprises SIC category 3320.

METAL Dummy $=1$ for Metal Working Sector which comprises SIC categories 3810 3819.

GARM Dummy $=1$ for Garment Sector which comprises SIC category 3220.

TEXTILE Dummy $=1$ for Textile Sector which comprises SIC categories 3210-3219.

Means of Variables (standard deviations are in ( ) parentheses, $\mathrm{N}$ is the number of observations)

$\begin{array}{llllll} & \text { Round 1 } & \text { Round 2 } & \text { Round 3 } & \text { Round 4 } & \text { Round 5 } \\ & 44 & 41 & 49 & 74 & 77 \\ \text { N } & & & & & \\ \text { Shares in Value-added } & & & & & \\ \text { Skilled labour } & 0.15(0.14) & 0.13(0.11) & 0.11(0.10) & 0.09(0.12) & 0.11(0.13) \\ \text { Unskilled labour } & 0.25(0.20) & 0.28(0.21) & 0.32(0.22) & 0.29(0.18) & 0.31(0.21) \\ \text { Capital } & 0.60(0.27) & 0.59(0.25) & 0.57(0.25) & 0.60(0.21) & 0.58(0.24) \\ & & & & & \\ \text { Ln (unskilled wages) } & 9.9(0.33) & 10.2(0.32) & 10.3(0.37) & 10.6(9.3) & 10.9(0.26) \\ \text { Ln (skilled wages) } & 10.5(0.24) & 10.9(0.23) & 11.0(0.25) & 11.5(0.29) & 11.9(0.46)\end{array}$


